ENTREPRENEURSHIP AND SUSTAINABILITY ISSUES

ISSN 2345-0282 (online) http://jssidoi.org/jesi/

2019 Volume 6 Number 4 (June)

http://doi.org/10.9770/jesi.2019.6.4(10)

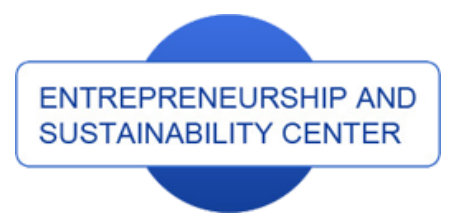

Publisher

http://jssidoi.org/esc/home



CASPA

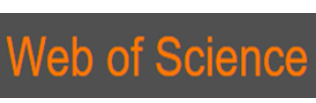

Clarivate
Analytics

\title{
ENTREPRENEURSHIP IN PALM FRONDS RECYCLING: A JORDANIAN CASE*
}

\author{
Ahmad Yousef Areiqat ${ }^{1}$, Asaad Hameed Al-Ali ${ }^{2}$, Hussein Mohammed Al-Yaseen ${ }^{3}$ \\ ${ }^{1,2,3}$ Al-Ahliyya Amman University, Business School, Al-Saro, Al-Salt, Balqa Governorate, Amman, Jordan \\ E-mails:를madareiqat@ammanu.edu.jo; ${ }^{2}$ a.alali@ammanu.edu.jo; ${ }^{3}$ hyaseen@ammanu.edu.jo (corresponding author)
}

Received; 21 February 2019; accepted 10 April 2019; published 30 June 2019

\begin{abstract}
This research paper argues that date palm fronds are feasible for recycling in bitmus production (organic agricultural soil) and have a good potential as an organic fertilizer. Entrepreneurial projects urge manufacturers to reconsider the use of these wastes of raw materials, and try to preserve them for organic agricultural soil and organic fertilizers' liquid to be used for various plants and trees. This could help in preserving the environment and reducing the consumption of natural resources. The project aims to benefit from the wastes of palm trees in $\mathrm{Al}$ Ghor, Jordan, mainly date palm fronds which are abundant (They are presently burned, causing pollution and harm for farmers as well as the soil, the environment and the local community). Such fronds are transformed into useful forage for nutrient animals, livestock and soil fertilizers. The products from this project will be of high value for farmers and can be available as an alternative for imported fertilizers at preferable costs. In addition the produce will contribute in overcoming the shortage of forage materials in Jordan.
\end{abstract}

Keywords: recycling; palm fronds (Phoenix dactylifera); bitmus, organic fertilizer; Jordan; entrepreneurship; sustainability

Reference to this paper should be made as follows: Areiqat, A.Y.; Al-Ali, A.H.: Al-Yaseen, H.M. 2019. Entrepreneurship in palm fronds recycling: a Jordanian case, Entrepreneurship and Sustainability Issues 6(4): 1694-1703. http://doi.org/10.9770/jesi.2019.6.4(10)

JEL Classifications: M13, L6

Additional disciplines: Ecology and Environmental Engineering

\section{Introduction}

Jordan is a small developing country in the Middle East with a limited natural resources, with the population size estimated to $(10,093,380)$ million and $(18.6 \%)$ unemployment rate for Jordanian's (DOS, 2018). Jordan is striving for its social and economic survival due to its location in an unstable region, with a total area of $(89,342) \mathrm{sq} . \mathrm{km}$

* This research was supported by Al-Ahliyya Amman University, Jordan 
(of which $99 \%$ is land and $1 \%$ is water) (Al-Yaseen and Al-Jaghoub, 2012). The Jordan Valley called (Ghor AlUrdon or Al-Ghawr) forms the west part of Jordan and it applies to the lower course of the Jordan River (See Figure 1).

Ghor Al-Urdon is a long and very narrow; it is $105 \mathrm{~km}$ long and when reach Dead Sea becomes $20 \mathrm{~km}$ wide; it is the deepest and lowest valley in the world $(-212$ to $-400 \mathrm{~m})$ below sea level; Ghor Al-Urdon is several degrees warmer than other adjacent areas, fertile soils and water made it supportive for palm tree (in 2018 it reached 600,000 trees) (DOS, 2018). Palm trees need to be cleaned twice anually by removing dry fronds, farmers have to process and remove dry fronds throughout burning it. This process of buring dry fronds affect heavily the environment in Jordan and Ghor Al-Urdon in particular. This research attempts to envestigate the process of avoiding this way in dry fronds disposal through recycling and waste management to minimize the waste and improve the climate and environment.

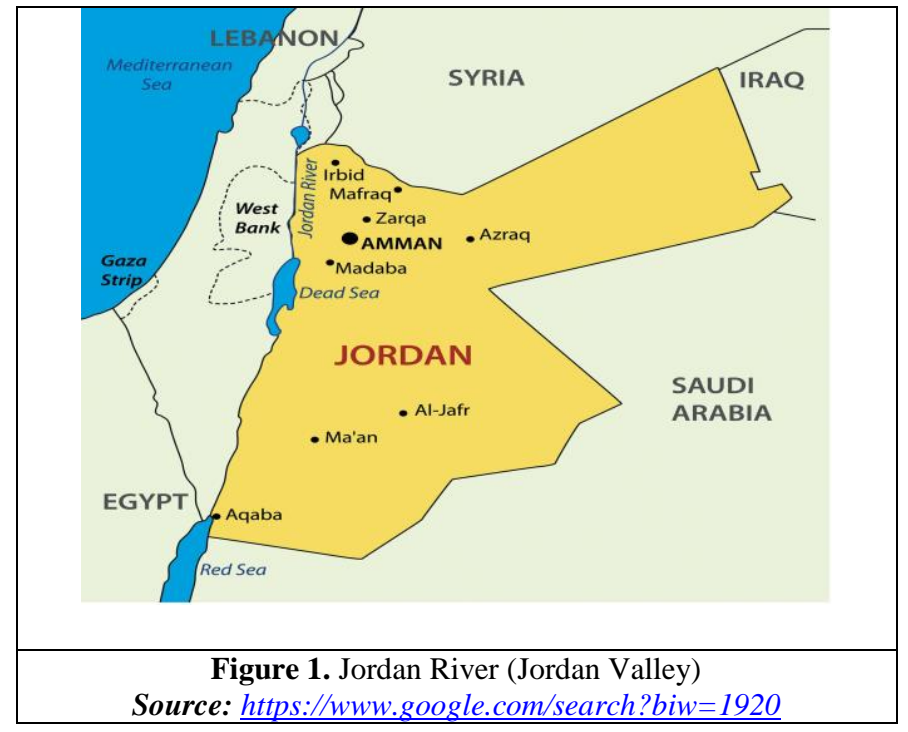

The purpose of of Recycling and waste management are to minimize and recycle the waste, recover energy and finally dispose the waste. For example, these principles apply to agricultural industrial wastes such as date palm fronds and palm oil residues as they do to municipal waste. Also, the utilization of renewable energy resources is strategically viable as it can contribute to the sustainability of energy supply while minimizing the negative impacts of energy generation on the environment. The efficient use of oil palm biomass other than the palm oil itself for food consumption is a promising method to obtain more energy from oil palm plantations (Abdullah and Sulaiman, 2013). For grinded date palm trees much applications, it was confirmed that they can provide additional benefits of decreasing water evaporation from the soil surface, helping control weed invasion, dust suppression, helping prevent soil erosion loss by wind or water, providing thermal stabilization by keeping soil cooler in hot weather and warmer in cool weather (Ashworth and Harrison, 1983). But for the purpose of successful recycling we propose these two projects as feasible for recycling in Bitmus production (organic agricultural soil) and a good potential as organic fertilizer.

This research paper is structured as follows: it starts by an introduction about Jordan and mainly Ghor Al-Urdon, and the purpose of this research (environmental problem) when dry fronds disposal, also it includes the main processes which are recycling, waste management, recycled products extracted from palm fronds in Jordan. The second section is relevant literature about palm trees, fronds, ferilizers. The third section is an attempt to develop a theoretical framework to be followed when applying the process of dry fronds disposal. Then the two proposed 


\section{ENTREPRENEURSHIP AND SUSTAINABILITY ISSUES}

ISSN 2345-0282 (online) http://jssidoi.org/jesi/

2019 Volume 6 Number 4 (June)

http://doi.org/10.9770/jesi.2019.6.4(10)

projects from dry fronds disposal were explored. The main challenges facing similar ventures in the future were highlighted. We conclude by specifying our contributions to the research and practice of entrepreneurship in the industry of recycling, ending up with the summary and recommendations.

\section{Palm trees in Jordan}

Sulaiman et al., 2015, in their feasibility study of gasification of oil palm fronds, found that oil palm fronds are feasible for gasification and have a good potential as a renewable energy source. (El-deeb, 2017) attempted in her study to find methods to link these materials with Egyptian handicrafts using new treatments in manufacturing with the cradle to cradle idea to produce compressed panels, wallpapers and other objects used in interior design. She asserted that $90 \%$ of palm fronds are burned every year in Egypt. This causes environmental pollution and is a waste of sustainable construction materials that include highly recyclable contents, rapidly renewable and biodegradable products, and local resources. A similar study indicated that oil palm fronds are feasible for gasification and have a good potential as a renewable energy source (Sulaiman et al., 2015).

Sadik et al., 2012, tried to produce high quality organic fertilizer at a large scale using abundant energy resources (Date palm trees mulch produced from grinded leafs, trunks and roots) from local farms. Date palm trees mulch (DPM) was mixed with fresh farmyard manure (FYM) as nitrogen source. The results confirmed that complete date palms trees could be recycled biologically into organic product that has the criteria of organic fertilizers, soil stabilizers and soil plantation. Also it was confirmed that the application of a mixture of manure and bio solids is considered the best practice that is commonly used by farmers (Rigane and Medhioub, 2011). Compared to individual fertilizers (such as nitrogen, phosphorus, and potassium), animal manures contribute significantly to soil fertilization. Also, sustained use of manures can improve organic substance and the structure of soils (Benabderrahim et al., 2018).

Nordin et al., 2017, showed that despite of being a biomass waste, oil palm fronds could be used as a starting material for the production of bio-composites for high performance applications. The substitution of natural fibers to petroleum-based materials would reduce the dependency on imported oil, thus contributing to costeffectiveness. At the same direction, another study was conducted for date palm fronds showed that boards made of date palm pruning residue fibers have better properties than the MDF (Medium Density Fiberboard) property requirements which was recommended by ASTM and EN standards particularly inspecting mechanical properties. In addition, the formaldehyde ( $\mathrm{HCHO}$ ) emission of the panels showed that almost all the boards met the minimum requirement according to EN 120 especially for the panel bonded with MUF resin. Therefore, Date palm could be an alternative material for the manufacturing of MDF (Hosseinkhani et al., 2015).

This study is considered one of the rare studies in the Arab world, especially that most of the foreign studies are concerned with the recycling of palm oil, which is abundant in Asia and Africa with little emphasis on date palm fronds. Considering the large and consistent supply, date palm fronds could be a promising source of organic fertilizer and bitmus production (Organic Agricultural Soil). In the present project, technical feasibility of date palm fronds is studied experimentally via standard tests in the Jordanian (National Center for Agricultural Research and Extension, Directorate of Laboratories and Quality Control) for the proposed organic fertilizer liquid and also in the (Feed Analysis Laboratory) to determine the basic characteristics of a sample of date palm feed. Inclusive analysis is conducted to determine the analyzed results and compare them with some related studies. With the present global concerns of the escalating prices and depleting sources, we hope this study will also add value to existing awareness on entrepreneurship in Jordan. Environment friendly materials need to be carefully selected and applied on the proposed design to "satisfy the current needs without compromising the ability of future generations to meet their needs" (Brundtland, 2013). 


\section{ENTREPRENEURSHIP AND SUSTAINABILITY ISSUES}

ISSN 2345-0282 (online) http://jssidoi.org/jesi/

2019 Volume 6 Number 4 (June)

http://doi.org/10.9770/jesi.2019.6.4(10)

These projects seek to build local capacity to identify and implement environmentally robust technologies for waste date palm fronds recycling and to assess their potential for generating new agricultural products, thereby reducing farmers' production costs. It also, assesses the feasibility of these technologies with respect to local socio-economic and environmental characteristics and demonstrates the benefits of selected through entrepreneurial projects.

\section{Research methodology}

For years, date palm fronds are pruned regularly but have little use and are mainly left on the ground in a huge quantity between palm trees to naturally decompose for soil conservation, erosion control and nutrient recycling. Farmers are required to dispose them properly in order to avoid mobilization problems within plantations (Sulaiman et al., 2015). On the other hand, excessive utilization of chemical fertilizers causes the deterioration of qualitative soil and agricultural production (Diacono and Montemurro, 2010; Singh et al., 2007).

Research and studies confirmed that the usage of organic fertilizers is increasing all over world (Agrawal, 2012), and only organic farming can restore the natural fertility of the damaged soil by increasing its soil organic substance which will improve crops productivity to feed the growing population. The same applies to the date palms which grow naturally between 15 to 40 degrees north latitude in the Sahara, and in the southern frontier of the Near East. The date palm is found throughout the Middle East, and in the northern, eastern, and southern areas of Africa.

\subsection{Proposed framework of Palm Trees Recycling}

As mentioned before, palm trees have to be cleaned twice a year from dry fronds. The steps of recycling are as follows (see Figure 2): Step one: fronds are collected from the farms and spread it in order to get dry; fronds have to be more than $70 \%$ dry; dry fronds are collected again to be grinded into smaller pieces called dry hay ( 3 to 7 $\mathrm{cm}$ lenghth) as required using a modified special machines called (Garouche) for this purpose; it is noticeable that for each $(1000 \mathrm{~kg})$ grinded we get $(800 \mathrm{~kg})$ dry hay and around (180 to $200 \mathrm{kgs})$ dry fronds dust, Step two: what left from grinded dry fronds (dry fronds dust) is then saturate into a large holes for a period of time (3 to 6 months) based on the tempreture which is between 20 to 45 degree; through this period of time the content is flipped continuously; after that, we seprate the content into two parts (dry fronds dust and liquid part); the first part which is dry fronds dust then grinded again smoothly and it becomes (Bitmus); the second part (liquid) is processed using special type of Bacteria and Fungus (Figure 2). 


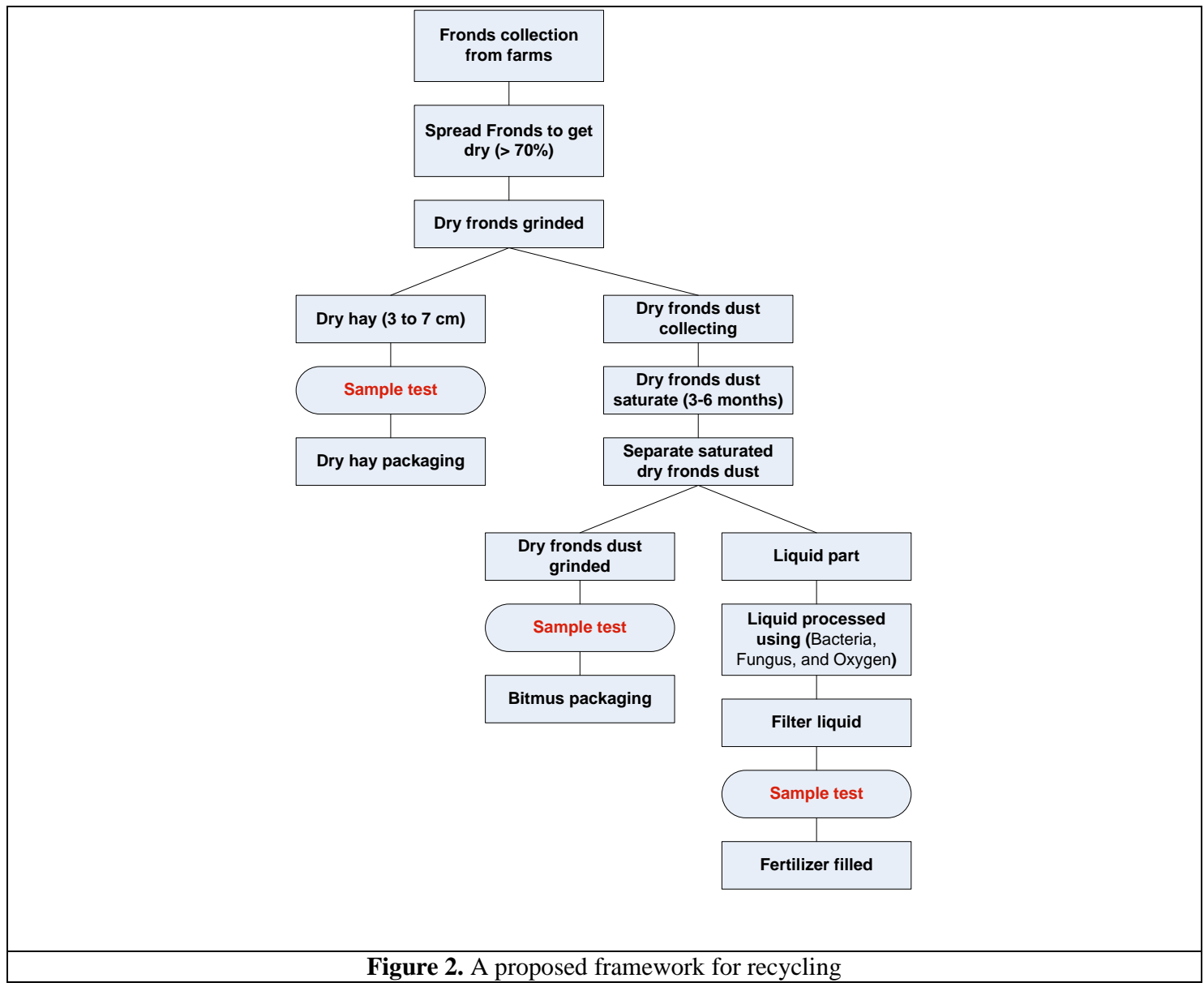

\section{Palm Trees: The Two Jordanian Entrepreneurship projects}

We believe that there is an interesting project in recycling through producing two types of agricultural projects from date palm fronds: Bitmus (Organic Agricultural Soil) and organic fertilizer which could help in preserving the environment and reducing the consumption of natural resources. In Jordan, many difficulties are related to fertilization by cow manure such as handling, transportation and large amounts required to get the nutrient needs of plants. Therefore, the farmers and researchers are continuously looking for an alternative organic fertilizer from their natural ecosystem. Nonetheless, there are rare studies conducted at the present time on dealing with the impacts of these projects. So, this study is conducted taking into consideration that the Jordanian economy is facing many problems; two of the most imperious is the consistently high unemployment rates and lack of natural resources which these projects can contribute in solving these problems. The performance of the projects ensures the economic soundness of the country and act like a protective shield to economic shocks, especially in the developing countries where such types of research are limited. 


\section{ENTREPRENEURSHIP AND SUSTAINABILITY ISSUES}

ISSN 2345-0282 (online) http://jssidoi.org/jesi/

2019 Volume 6 Number 4 (June)

http://doi.org/10.9770/jesi.2019.6.4(10)

\subsection{Bitmus Project: Organic Agricultural Soil}

Bitmus or organic agricultural soil composed mostly of plant material; here in this project, Bitmus is composed from dry fronds dust, Bitmus is essential for plant growth. Conversion of plant waste into organic agricultural soil, which can be useful for agriculture of all types as an alternative to imported Bitmus. The project is unique and innovative, hoping to be the first of its kind in the Arab world.

\section{Mechanism of the project implementation:}

1- Collection of plant waste that is a burden on the environment where it becomes a disgusting health.

2- Grind those wastes and cut them into small pieces to speed up the organic transformation process.

3- Collecting the milled waste in water ponds and adding microorganisms (bacteria and Fungi) to accelerate the process of decomposition of the original materials for 3-6 months according to the temperature.

4- Drying the subsequent solids, then softening them and packing them in bags or containers.

\subsection{Organic Fertilizer Project}

Organic Fertilizer is a plant fertilizer that is derived from dry fronds dust. Take extracts of the Bitmus dipped from the holes and assemble them into a container for transformation, so that it produces organic fertilizer, liquid and natural nutrient that can be used for all types of plants and trees.

Mechanism of the project implementation:

I- Extracting Bitmus through dewatering by pumps.

2- Collecting liquid extracted in special containers.

3- Adding beneficial microorganisms to make the chemical transformations needed to produce the main nutrients of plants naturally away from chemicals.

4- Feeding microorganisms with natural nutrients to accelerate decomposition.

5- Filtering the extract and pack the products into special containers to be ready for utilization.

\section{Bitmus and Organic Fertilizer: Results and Tests}

A sample of Bitmus has been sent to the lab (National Center for Agricultural Research and Extension, Directorate of Laboratories and Quality Control, Feed Analysis Laboratory, Jordan) for test the contents, results of the test showed that the sample includes material such as: protein $(7.25 \%)$; fiber $(34.29 \%)$; moisture $(11.04 \%)$; ash $(14.03 \%)$, NDF (60.23\%); ADF (40.23\%); fat (2.78\%); and carbohydrate (51\%). The second test was for the organic fertilizer liquid, and the result of the test is presented in Table 1.

\begin{tabular}{|l|l|l|l|l|}
\hline \multicolumn{5}{|c|}{ Table 1. Organic Fertilizer Liquid tests } \\
\hline \multicolumn{2}{|c|}{ Test name } & \multicolumn{1}{|c|}{ Result } & \multicolumn{2}{c|}{ Operation number: F/18/173 } \\
\hline Laboratory number: 468/2018 & 7.3 & & Test method No. \\
\hline Test No. & $\mathrm{pH}$ & 25.5 & $\mathrm{dS} / \mathrm{m}$ & 973.04 \\
\hline 1 & $\mathrm{pC}$ & 0.8 & $\mathrm{wt} / \mathrm{v} \%$ & \\
\hline 2 & Organic matter & $\mathrm{wt} / \mathrm{v} \%$ & \\
\hline 3 & Organic Carbon & 0.5 & $\mathrm{ppm}$ & $\mathrm{AOAC} 965.09$ \\
\hline 4 & $\mathrm{Fe}$ & 128.5 & $\mathrm{ppm}$ & $\mathrm{AOAC} 965.09$ \\
\hline 5 & $\mathrm{Mg}$ & 2581.5 & $\mathrm{ppm}$ & $\mathrm{AOAC} 983.02$ \\
\hline 6 & $\mathrm{~K}$ & 1342.5 & $\mathrm{wt} / \mathrm{v} \%$ & $\mathrm{AOAC} 983.02$ \\
\hline 7 & $\mathrm{Na}$ & 0.08 & $\mathrm{wt} / \mathrm{v} \%$ & $\mathrm{AOAC} 928.02$ \\
\hline 8 & $\mathrm{C} 1$ & 1.0 & $\mathrm{gm} / \mathrm{cm}^{3}$ & QC-01-016 \\
\hline 9 & Density &
\end{tabular}




\section{ENTREPRENEURSHIP AND SUSTAINABILITY ISSUES}

ISSN 2345-0282 (online) http://jssidoi.org/jesi/

2019 Volume 6 Number 4 (June)

http://doi.org/10.9770/jesi.2019.6.4(10)

Most studies were conducted on the same issue recently, but our project started earlier and is considered a unique project because we convert the palm waste into fodder for ruminant animals such as cows, cattle, sheep, and camels etc., as hay and fodder. Most of the previous studies and projects focused on one aim either to produce hay, or to produce compost only. However, this project deals with the two functions, producing forage and producing bitmus and at the same time producing organic fertilizer. There was no similar project that produces bitmus. Even similar projects produce compost by simple and traditional ways, and production of bitmus needs more materials and certain measures that cannot be applied easily. In producing bitmus, we imitate the same method of bitmus production in North Europe and North America.

The proposed project produces three products at the same time from grinding palm waste to producing hay. The waste of producing hay has been used to produce bitmus, and after bitmus preparation we have the liquid which results from bitmus to produce organic fertilizer with high standard quality. Our fertilizer consists of three components including biological organisms, organic abstract and the mineral component. This is why our project produces a unique fertilizer that collects three elements in one product (bio, organic and mineral) at the same time.

The proposed fertilizer acts as three in one (organic, biological, and mineral fertilizer), since this product is unique for its divergence and stimulant moss up grading shape of compost that is rich with organic matter, organic fertilizer and easy to use for seed plantation but compost that does not act as bitmus.

Moreover, the liquid organic fertilizer is saturated with beneficial bacterial (bacillus type) that helps to enrich the plant root environment with soluble fertilizer and upgrade the fertilizer absorption by plants which is reflected on plant production and its size. This advantage is not found in other organic fertilizers, as our fertilizer acts as nutrition for plants and conditioner for soil; which decreases soil salinity, and its PH. It also acts as a challenging factor for mineral fertilizer, keep it in the root and releases it slowly as the according to the plant needs.

\section{Challenges facing the Projects}

It is reported that in various countries up to $40 \%$ of new emerging firms fail within the first 2 years of life (Vivarelli, 2013). There are various factors and challenges which are associated with the low performance of small firm in the developing countries that face unfavorable economic situation, lack of appropriate government policies, poor infra-structural facilities, higher operating costs, corruption (Abdullahi \& Sulaiman, 2015; Hafeez et al., 2013), low level of capabilities, insufficient entrepreneurial competencies, difficulty in accessing technology and low productivity (Hussain et al., 2015) and mostly inappropriate and inefficient utilization of the firm resources (Rauch \& Hatak, 2016; Bloodgood, 2014; Hilkevics and Semakina, 2019). For the case of entrepreneurial projects, the lack of understanding how small and medium firms can develop essential capabilities and secure their future performance is considered among the challenges that deter success (Greer et al., 2016). However, insights from the United States show a positive indicator where about $50 \%$ of all new establishments get through five years or more and about one-third are still operating and running their business after 10 years (SBA, 2014).

We believe that successful entrepreneurs are often described as tenacious, passionate, flexible, and natural risktakers. They are visionary thinkers, confident, and tolerate ambiguity. Even if an entrepreneur possesses all of these character qualities, a successful business venture requires a viable business concept and a realistic plan. Technically, most of the raw material cannot be readily assessed because major plantation companies are quite reluctant to bring biomass materials beyond their plantation borders. This general logistical issue of transporting the product to the processing points is costly and could be even higher than the cost of the raw material itself. 


\section{ENTREPRENEURSHIP AND SUSTAINABILITY ISSUES}

ISSN 2345-0282 (online) http://jssidoi.org/jesi/

2019 Volume 6 Number 4 (June)

http://doi.org/10.9770/jesi.2019.6.4(10)

\section{Recommendations}

The Jordanian government should exert more effort to review and develop related policy and programmers to support the expansion of alternative agricultural resources and feedstock sources for sustainable development of power generation in the country.

Further experimentation with other variable factors will be conducted to confirm our findings with date palm frond fertilizer and bitmus to allow comparisons with similar studies. Date palm waste may create problems of supply because, though they are produced in large quantities, they are quite dispersed and transport costs for this bulky raw material may become more or less an obstacle, so further studies are recommended to make more economic surveys. Additionally, full production trials must be conducted to confirm our pilot-scale results. Moreover, we believe that there are grounds for further investigation regarding entrepreneurial projects from other waste products in Jordan.

\section{References:}

Abdullah, N., Sulaiman, F. (2013). The Oil Palm Wastes in Malaysia. Chapter 3 in Biomass Now, Sustainable Growth and Use, edited by Miodrag Darko Matovic. IntecOpen. http://dx.doi.org/10.5772/55302, visited on Jan. 3/

Abdullahi, I.I., Sulaiman, C. (2015). The Determinants of Small and Medium-sized Enterprises Performance in Nigeria. Advances in Economics and Business, 3(5), 184-189. http://dx.doi.org/10.13189/aeb.2015.030504

Agrawal, M. (2012). Book Foreword: Organic Fertilizers: Types, Production and Environmental Impact. Eds. Singh, R. Nova Science Publishers, Inc. New York.

Al-Yaseen, H. and Al-Jaghoub, S. (2012). Success and Failure of e-Learning Projects: Alignment of Vision and Reality, Change and Culture, Journal of Emerging Trends in Computing, $27(2), \quad 284$. https://www.ammanu.edu.jo/English/pdf/StaffResearch/IT/749/Success $\% 20$ and $\% 20$ Failure\%20of\%20eLearning\%20Projects\%20Alignment \%20of\%20Vision\%20and\%20Reality,\%20Change\%20and\%20Culture.pdf

Benabderrahim, M. Elfalleh, W. Belayadi, H. and Mansoor, H. (2018). Effect of Date Palm Waste Composts on Forage Alfalfa Growth, yield, seed yield and Minerals uptake. International Journal of Recycling of Organic Waste in Agriculture, 7:1-9. https://doi.org/10.1007/s40093-017-0182-6

Bloodgood, J. (2014). Enhancing the Resource-based View of the firm: Increasing the Role of Awareness. Strategic Management Review, $8(1), 61-75$.

Brundtland, G. (2013). La Trobe University Sustainability Plan 2013-2017. https://www.latrobe.edu.au/sustainability , visited on Dec. 16/ 2018.

Department Of Statistics (2018) http://dosweb.dos.gov.jo/. Accessed December, 2018.

Diacono, M., Montemurro, F. (2010) Long-term Effects of Organic Amendments on Soil Fertility: a review. Agron Sustain Dev. 30(2), 401-422. http://doi.org/10.1051/agro/2009040 (visited on 30 Dec. 2018).

El-deeb, A. (2017). Recycling Agricultural Waste as a Part of Interior Design and Architectural History in Egypt. International Journal on: The Academic Research Community Publication, 1(1) http://doi.org/10.21625/archive.v1i1.116

Frederick, H., O’Connor, A., Kuratko, D. (2019). Entrepreneurship: Theory/ Process/ Practice. 5th Asia- Pacific Edition. Cen gage Learning Australia Pty Limited. 


\section{ENTREPRENEURSHIP AND SUSTAINABILITY ISSUES}

ISSN 2345-0282 (online) http://jssidoi.org/jesi/

2019 Volume 6 Number 4 (June)

http://doi.org/10.9770/jesi.2019.6.4(10)

Greer, C.R., Carr, J.C., Hipp, L. (2016). Strategic Staffing and Small-firm Performance. Human Resource Management, 55(4), 741-764. http://dx.doi.org/10.1002/hrm.21693

Hafeez, M. Shariff, M., Bin Mad Lazim, H. (2013). Does Innovation and Relational Learning Influence SME Performance? Empirical Evidence from Pakistan. Asian Social Science, 9(15), 204. http://dx.doi.org/10.5539/ass.v9n15p204

Hilkevics, S.; Semakina, V. (2019). The Classification and Comparison of Business Ratios Analysis Methods. Insights into Regional Development, 1(1), 47-56. http://doi.org/10.9770/IRD.2019.1.1(4)

Hosseinkhani, H., Euring, M. and Kharazipour2, A. (2015). Utilization of Date Palm (Phoenix dactylifera L.) Pruning Residues as Raw Material for MDF Manufacturing, Journal of Materials Science Research 4, 1. http://dx.doi.org/10.5539/jmsr.v4n1p46

Hussain, J., Ismail, K., Akhtar, C.S. (2015). Market Orientation and Organizational Performance: Case of Pakistani SMEs. Arabian Journal of Business and Management Review 5:39.

Nordin, N. Sulaiman, O. Hashim, R., Kassim, M. (2017). Oil Palm Frond Waste for the Production of Cellulose Nan-ocrystals. Journal of Physical Science, 28(2), 115-126. https://doi.org/10.21315/jps2017.28.2.8

Rauch, A., Hatak, I. (2016). A Meta-analysis of Different HR-enhancing Practices and Performance of Small and Medium- sized Firms. Journal of Business Venturing, 31(5), 485-504. https://doi.org/10.1016/j.jbusvent.2016.05.005

Rigane, M., Medhioub, K. (2011) Assessment of Properties of Tunisian Agricultural Waste Composts: Application as components in reconstituted anthropic soils and their effects on tomato yield and quality, Resource Conservation Recycle 55: 785-792. https://doi.org/10.1016/j.resconrec 2011.03.012 Visited on 25 Dec. 2018

Sadik, M. Al Ashhab, A. Zahran, M. and Alsaqan, F. (2012). Composting Mulch of Date Palm Trees through Microbial Activator in Saudi Arabia. International Journal of Biochemistry and Biotechnology, 1(5), 156-161. http://internationalscholarsjournals.org International Scholars Journals.

SBA-Small Business Administration. (2014). Frequently asked questions about small business, SBA office of advocacy. https://www.sba.gov/advocacy/frequently-asked-questions-about-small-business

Singh, R. Sharma, R., Tyagi, S. (2007). Pre-harvest Foliar Application of Calcium and Boron Influences Physiological Disorders, Fruit Yield and Quality of Strawberry (Fragaria x ananassa Duch.), Sci Hortic (Amsterdam) 112: 215-220. https://doi.org/10.1016/j

Sulaiman, S. Balamohan, S., Moni, M., Atnaw, S., Mohamed, A. (2015). Feasibility Study of Gasification of Oil Palm Fronds, Journal of Mechanical Engineering and Sciences (JMES), 9, 1744-1757, December. https://doi.org/10.15282/jmes.9.2015.20.0168

Vivarelli, M. (2013). Is Entrepreneurship Necessarily Good? Micro-economic Evidence from Developed and Developing Countries, Industrial and Corporate Change. https://doi.org/10.1093/icc/dtt005 
Ahmad Yousef AREIQAT

ORCID ID: https://orcid.org/0000-0003-0379-7409

Asaad Hameed AL-ALI

ORCID ID: https://orcid.org/0000-0001-9981-1505

Hussein AL-YASEEN

ORCID ID: https://orcid.org/0000-0003-0876-5975

Register for an ORCID ID:

https://orcid.org/register

Copyright (C) 2019 by author(s) and VsI Entrepreneurship and Sustainability Center

This work is licensed under the Creative Commons Attribution International License (CC BY).

http://creativecommons.org/licenses/by/4.0/

c) (i) Open Access 